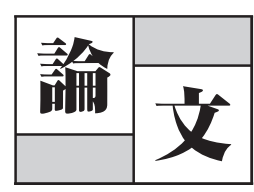

\title{
廃棄ポリエステルコードを素材とする吸音材の成形と吸音特性
}

\author{
倉 橋 直 也**木 村 照 夫*
}

\section{Sound Absorbing Property of Porous Material by Using Polyester Fiber Waste}

\begin{abstract}
Kurahashi, Naoya*/Kimura, Teruo*
Polyester waste generated from a water jet loom in the weaving process is one of the typical industrial fiber wastes. The development of a recycling system for such fiber wastes has been strongly expected so far. In this study, the recyclability of polyester wastes as a sound absorption material was discussed. As a result, it was cleared that the sound absorption material can be obtained by heated compression molding combined with a PLA binder and fiber wastes, and higher sound absorption properties are obtainable if the defiberization of the waste is increased.
\end{abstract}

Key words : Recycle/Polyester fiber waste/Porous sound absorbent/Sound absorbing property

\section{1. 緒言}

近年，廃裹物からの資源回収は循環型社会の構築に必要 不可欠であり，種々の廃裹物について再資源化に関する技 術開発が進められている1).しかし, 廃裹纎維製品に関し ての再資源化技術の開発は停滞して扮り, 年間約 200 万 $\mathrm{t}$ 排出される瀻維廃材に対してのリサイクル率は $10 \%$ 程度 に留まっている2゙.

一方で，近年になり騒音が社会的な問題として認識され， その対策としての防音材の開発が広く行われている3. 特 に, 多孔質型吸音材は軽量性と防音性を兼備していること から広い用途に利用されている。一般には，グラスウール やロックウールに代表される無機繊維が, その不燃性を生 かして建材として多用されているが, 資源循環型社会構築 の必要性から, より環境負荷を低減し得る他素材への転換 が模索されている. 種々の素材の中で, ポリエステル (PET) 瀻維については化学的な手法による再生が高収率 で可能であり，繰り返しリサイクル性に富む材料として注 目されている4.

以上の背景から, 本研究ではPET 繊維廃材の一例とし て, PET 織布の製造工程中に大量に排出される工程屑（捨 て耳）のリサイクル用途開発と環境調和型の吸音材の開発

* 京都工芸繊維大学工芸科学研究科先端ファイブロ科学専攻 Kyoto Institute of Technology Division of Advanced Fibro Science

京都市左京区松ヶ崎御所海道町（

Goshokaido-cho, Matsugasaki, Sakyo-ku, Kyoto, Japan 2009.6.5 受理
を目的に, PET 捨て耳の多孔質吸音材の素材としてのリ サイクル性に着目した。

捨て耳は工程屑であり, 後述のように特殊な形状を持つ ことから，これを緎維多孔質材の安定した形状の素材とし て利用する為に反毛化を行い, さらには成形品形状の保持 を目的として熱可塑性繊維をバインダーとして用いた。こ こで，反毛 (開繊) とは織布や繊維束等の状態にある繊維 材料を交綿機（Carding machine）を用いて繊維同士が均 一かつ緩やかに交絡した棉（ウェブ）にする事を意味する. 本報では，特に捨て耳の反毛化（開繊状態）が成形品の吸 音特性に及ぼす影響を調べ, 吸音材としての最適な開繊状 態を考察した。

\section{2. 試料の作製}

\section{1 使用材料}

成形素材として用いる捨て耳は, Fig. 1 (a) に示すウォー タージェット織機で PET 繊維織物を生産する際に生じ, これは連続したPET 製のキャッチャー糸に, 長さ数 $\mathrm{cm}$ の 切断された緯糸が絡まった工程屑である. その構造の模式 罒を Fig. 1(b)に示す. 捨て耳の状態は, 織物の種類によ り異なることから，本報では種々の捨て耳に対応するため に Fig. 2 に示すような密度の異なる 3 種類の捨て耳を実験 対象とした。すなわち, 平均直径が $3 \mathrm{~mm}$ (Cord A), 5 $\mathrm{mm}$ (Cord B) 及び $8 \mathrm{~mm}$ (Cord C) の 3 種類の捨て耳を 用いた。ただし，これらの捨て耳を構成する PET 纎維は, いずれも繊維径が $26 \mu \mathrm{m}$ の同一のものである。ここで, 捨て耳が円筒形状であると仮定すると, Cord A， B，Cの 捨て耳密度は, それぞれ $56.8 \mathrm{~kg} / \mathrm{m}^{3}, 39.5 \mathrm{~kg} / \mathrm{m}^{3}$ 及び 


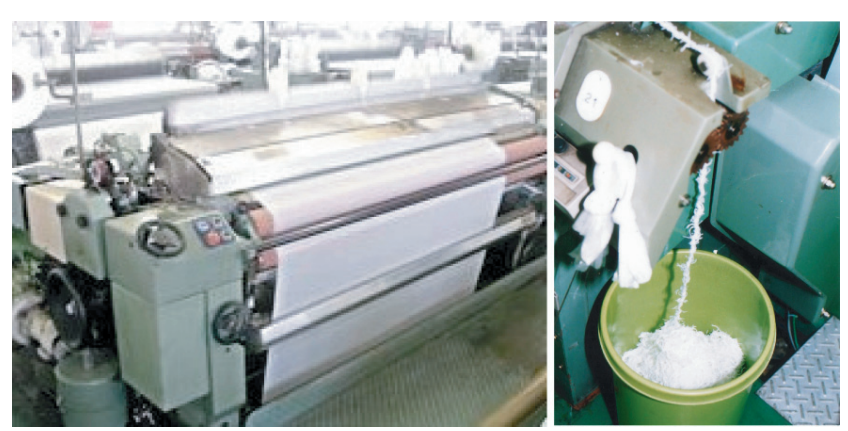

(a) Aspect of water jet loom and generation of polyester fiber waste

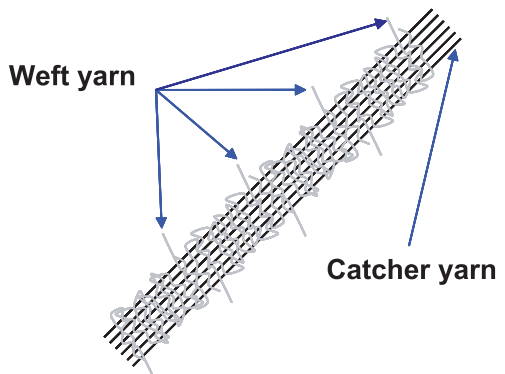

(b) Schematic model of polyester fiber waste

Fig. 1 Information of polyester fiber waste (Cord)

$23.4 \mathrm{~kg} / \mathrm{m}^{3}$ となる.キャッチャー糸に対して緯糸が密に 絡まっている場合には捨て耳密度は大きくなり, 緩やかに 絡まっている場合には小さくなる.

吸音材としての多孔質形状を保持する為のバインダーと しては, 平均繊維長 $65 \mathrm{~mm}$, 平均繊維直径 $23 \mu \mathrm{m}$, 融点 $163.5^{\circ} \mathrm{C}$ の PLA（Poly lactic acid）緘維（ユニチカファイ バー製，テラマック）を用いた。

\section{2 試料の成形}

捨て耳の反毛化には布を棉化する時に一般的に用いられ ているローラー型シリンダーカード機（大和工機製）を用 いた。ここで，用いたカード機は 6 つのシリンダーロール と 1 つのマスターロールから構成される. 各ロール表面に は微小な刃が付いて抢り，回転ロール間を開繊対象とする 材料が通過する事で, 繊維組織が分解され開繊を行う事が 出来る。その外観を Fig. 3 に示す. 捨て耳は連続的なコー ド状であることから，直接カード機に投入するとシリン ダーロールへの巻き付きが生じ, 目付けの安定したウェブ を得ることが困難であった。そこで，捨て耳を予めキャッ チャー糸長手方向に $50 \sim 60 \mathrm{~mm}$ 程度の長さに裁断した。 この裁断物と先述のバインダー纎維を仮混ぜした後にロー ラー型カードマシンに投入し，捨て耳とバインダー瀻維が 混合したウェブを作成した. Fig. 4 に得られたウェブの様 子を示す。このウェブを所定枚数積層することで予備成形 体とした。ここで, 開瀻状態が成形品の吸音特性に及ぼす 影響を明確にする為に，カーデイング回数 (Carding time, 以降 CT と称する）を 1 回 (CT 1), 3 回 (CT 3) 及び 5 回（CT 5) とする予備成形体を作成した。 バインダー含 有量は, 全ての予備成形体について総重量に対して $30 \mathrm{wt}$ \%で一定とした。形状を固定化させる為には, 予備成形体 をホットプレス機内に設置し, 上下面の加熱盤の温度を
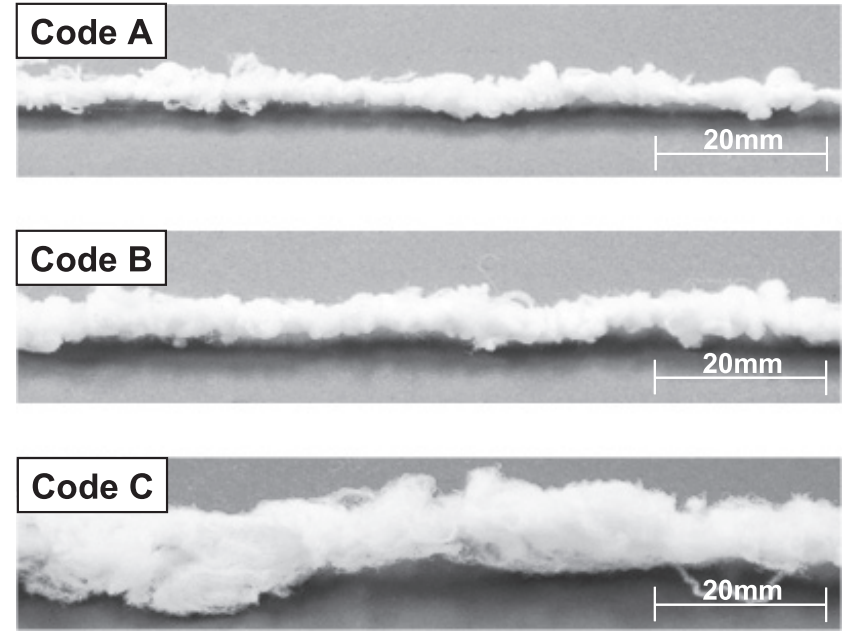

Fig. 2 Aspect of polyester fiber waste used

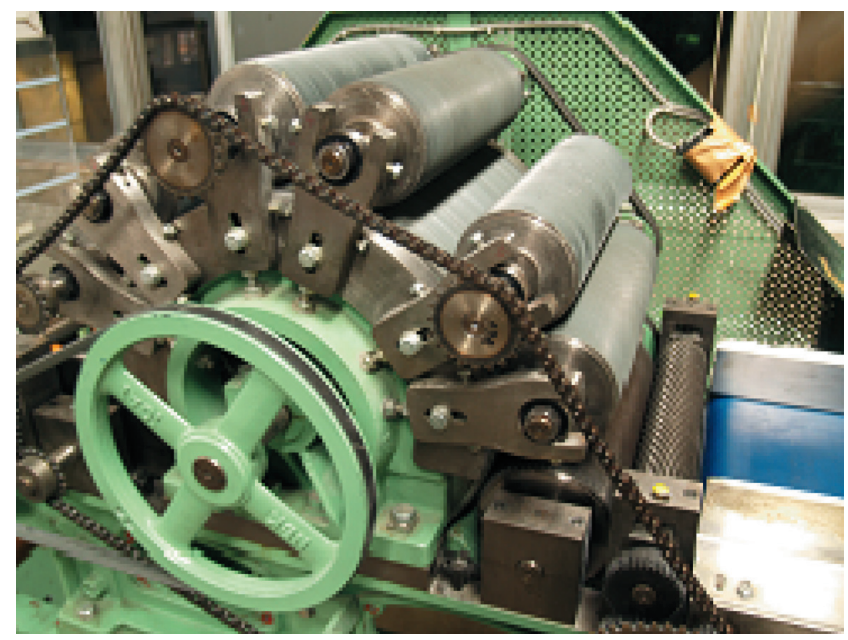

Fig. 3 Carding machine

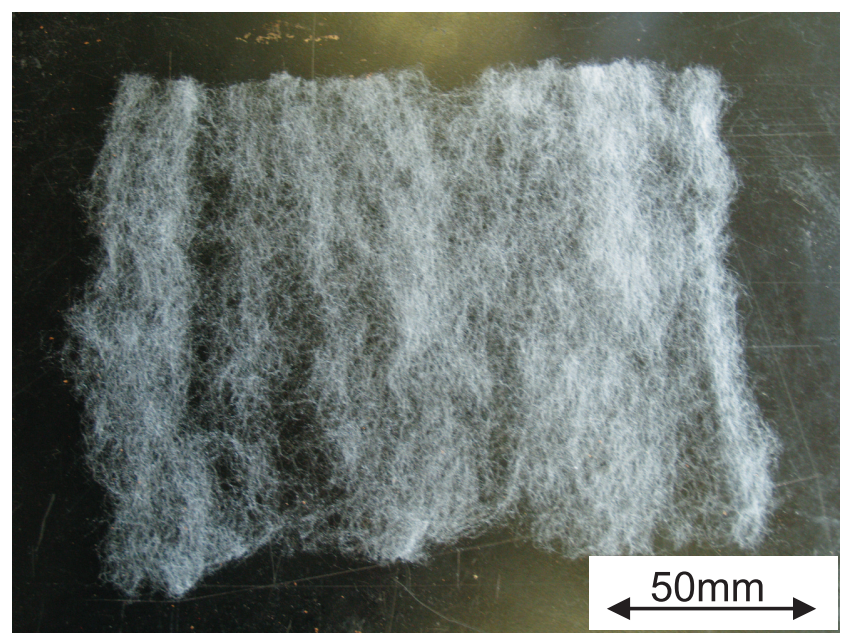

Fig. 4 Aspect of web carded

$165^{\circ} \mathrm{C}$ として加熱圧縮成形を行った。ここで, 試料内に設 置した熱電対による測定温度が一定となった後, 直ちに ヒーターの電源を切り, 圧力を保持したまま $60^{\circ} \mathrm{C}$ 以下に なるまで自然放冷した。成形品の厚みはアルミスペーサー を用いて $50 \mathrm{~mm}$ となるように調整した. Fig. 5 は成形品 の成形手順を整理したものである。実験に用いた成形品の 


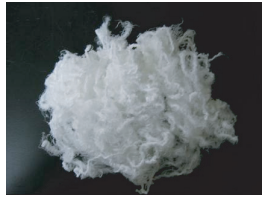

PET cord (initial)
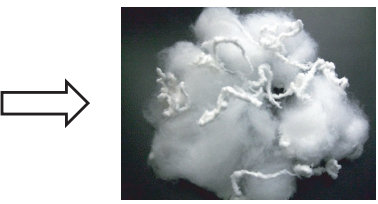

Mixture of cut PET cord and PLA binder

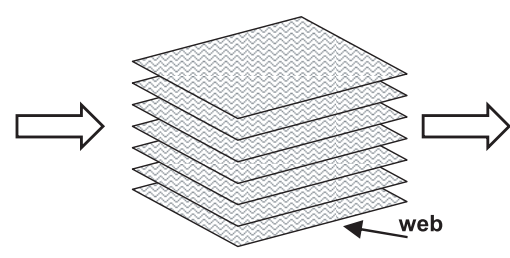

Laminated webs

(Pre-form)

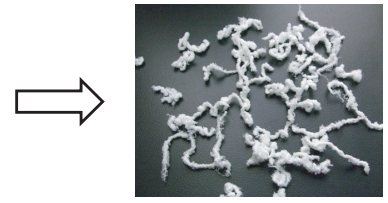

Cut PET cord

(60mm)

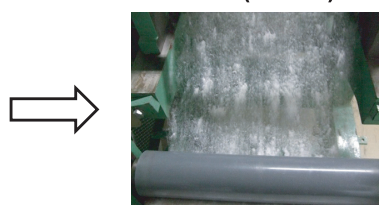
cord and PLA binder

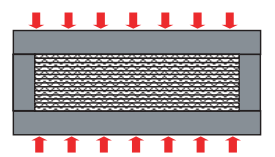

Heat press
Carding process of cut PET

Fig. 5 Molding process

Table 1 Sample specifications

\begin{tabular}{|c|c|c|c|c|}
\hline Sample & Material & Carding time & $\begin{array}{c}\text { Thickness } \\
(\mathrm{mm})\end{array}$ & $\begin{array}{l}\text { Density } \\
\left(\mathrm{kg} / \mathrm{m}^{3}\right)\end{array}$ \\
\hline A 1 & \multirow{3}{*}{ Cord A } & 1 & 50 & 32.1 \\
\hline A 3 & & 3 & 50 & 32.2 \\
\hline A 5 & & 5 & 50 & 32.4 \\
\hline B 1 & \multirow{3}{*}{ Cord B } & 1 & 50 & 32.0 \\
\hline B 3 & & 3 & 50 & 31.8 \\
\hline B 5 & & 5 & 50 & 32.4 \\
\hline C 1 & \multirow{3}{*}{ Cord C } & 1 & 50 & 31.8 \\
\hline C 3 & & 3 & 50 & 32.1 \\
\hline C 5 & & 5 & 50 & 32.3 \\
\hline
\end{tabular}

一覧を Table 1 に示す. 本報で対象とする成形品密度はい ずれも $32 \pm 0.4 \mathrm{~kg} / \mathrm{m}^{3}$ に揃えてある．以降は各成形品の呼 称に表中の Sample 記号を用いる.

\section{3. 実験及び評価方法}

\section{1 開繊状態の観察}

多孔質体の内部構造は，音波の伝播経路や流体通過時の 流路を構成することから，吸音特性及び通気特性に対して 本質的な影響を及ぼす事が知られている 成形体（ウェブ）の作成時に, 捨て耳密度及び CT 数によ り捨て耳の開繊状態が大きく異なる様子が観察された。成 形品は，ウェブを積層して成形する為に，ウェブ作成時の 開繊状態が成形品の内部構造に直接反映される。後述のよ うに本報では，音波は成形品の厚み方向に伝播する事から， ウェブ内の捨て耳の開繊状態が成形品の吸音特性に大きく 影響を及ぼすものと考えられる。

そこで，捨て耳密度と CT 数が開繊状態に及ぼす影響を 明確にする為に蛍光染色マッピング法を用いてウェブの表 面観察を行った。すなわち, 予め捨て耳及びバインダー緎
維を蛍光性染料及び黒色染料でそれぞれ染色し，種々の CT 数のウェブを作成し，暗室内で紫外線を照射する事に よって表面観察を行った。

\section{2 通気抵抗測定}

多孔質型の吸音材料は，微視的には材料中に小さな穴が 連続的に存在している. 多孔質材の吸音効果は，音圧によ り媒質に与えられた運動エネルギーが, 粒子と穴の壁面と の摩擦によって減衰される事で生じる。同様に, 多孔質材 における通気抵抗は，材料を通過する流体と壁面との摩擦 により発生する。このことから, 多孔質材料の吸音特性と 材料の通気抵抗には相関性があることが Delany ${ }^{6}$ や Miki $^{7)}$ により明らかにされている．また，通気抵抗の測定は簡便 であることから, 多孔質吸音材料の品質指標としても適し ており，JIS A 6303 ではグラスウール吸音材の品質を示 すパラメータとして規定している．このことから，本報の 成形品についても通気抵抗值と吸音特性の相関性を検討す るためにカトーテック社製の KES-F 8-AP 1 を用いて通 気抵抗值 $\sigma$ の測定を行った。通気抵抗值は(1)式により表 される。

$$
\sigma=\Delta P / V
$$

すなわち，多孔質材の通気抵抗は，材料の表面に対して 垂直方向に流入する空気の流速 $V$ と，材料の両端面にお ける圧力の差 $\Delta P$ を用いる事で導出出来る. 今回の実験 では, 流入空気流速は $4 \mathrm{~cm} / \mathrm{s}$ 一定とし $\Delta P$ を測定した。 被測定物は，後述する吸音特性の測定に用いた試料と同一 の試料を用いた。

\section{3 吸音性能測定}

現在，材料の吸音性能の評価には一般的には吸音率が用 いられている，吸音率の定量的な評価方法は，垂直入射吸 音率測定及び残響室法吸音率測定が一般的であり，本報で は垂直入射吸音率測定法を採用した。この測定法には，定 在波比法と伝達関数法があるが，近年では，吸音率だけで はなくより簡便に材料の固有の特性值である特性インピー ダンスと伝播定数も求めることができる伝達関数法が主流 となっている.

そこで，本報では伝達関数法 ${ }^{8}$ を用いて吸音率 $\alpha$ を導出 し，この值を対象に吸音性能の評価を行った。試料の背面 が剛体に密着している条件下では吸音率 $\alpha$ と特性イン ピーダンス $Z_{C}$ 及び伝播定数 $\gamma$ の間には $(2),(3)$ 式の関係 がある。

$$
\begin{gathered}
Z=Z_{C} \cdot \operatorname{Coth}(\gamma \cdot l) \\
\alpha=1-R^{2}=1-\left|\frac{Z \cdot \rho c^{-1}-1}{Z \cdot \rho c^{-1}+1}\right|
\end{gathered}
$$

ここで, $Z$ は音の入射面における比音響インピーダンス, $l$ は試料厚さ, $R$ は反射係数, $\rho$ は空気密度, $c$ は空気中 での音速を表している，すなわち，伝達関数法における測 定では, 反射係数 R を測定することにより吸音率 $\alpha$ を得 ることが出来る.

吸音率の測定は JIS 1405-2（伝達関数法による垂直入射 
吸音率測定法）に基づいて行った。測定機材には B\&K 社 製 Type 4206 のインピーダンス管を, 音響特性の解析に は松下テクノトレーディング社製の解析ソフト MS 1201 を用いた。性能評価は $1 / 3$ オクターヴ中心周波数において 行い，測定条件は試料背面に設置された剛壁面で音波が完 全反射すると考える剛壁密着とした。

\section{4. 結果と考察}

\section{1 開繊状態}

各 CT 数におけるウェブの開繊状態を蛍光染色マッピン グ法によって観察した結果を Fig. 6 に示す。ここで, 眓中 の鮮明な白色部が捨て耳, 鮮明な黒色部がバインダー繊維 を表している。図より, 程度の差は見られるものの, CT 数が 1 回の場合（A 1, B 1, C 1) では，いずれの Cord を用いた場合でも，鮮明な白色の塊がウェブ内に点在して いる様子が見られ，これは捨て耳の開繊不足を示している. しかし, CT 数が増加する事によりいずれのウェブにおい ても明らかな開繊不足部が減少している。但し, 捨て耳密 度の小さな Cord C については，CT1の場合においても 比較的良好な開繊状態が得られている。Fig. 7(a)，（b) は， それぞれ開繊不足部と開繊が進んだ部分の詳細な様子を示 している，図より明らかなように，開繊不足の場合には， キャッチャー糸から緯糸が分離されているものの, キャッ チャー糸は依然として繊維束状で残っている事が分かる. このような状態では, 繊維が局所的に密に集合している為 に繊維束を構成する繊維の多くは, 音波もしくは流体の通 過経路としての空隙部に露出しておらず，従って吸音率や 通気性に大きく影響すると考えられる繊維表面積は, 成形 品に含まれる PET 繊維全量に対して小さくなっているも のと考えられる。一方で，捨て耳の開繊が良好な場合には， キャッチャー糸も単繊維状に解されており, 捨て耳を構成 する PET 繊維とバインダー繊維が均一に交絡したネット ワーク状となり，このような場合には，成形品内部の空隙 部に接触する繊維が増加し, 成形品に含まれる PET 繊維 全量に対する繊維表面積は大きくなっているものと考えら れる。

\section{2 通気抵抗値}

CT 数と成形品の通気抵抗值との関係を Fig. 8 に示す. 図より明らかなように，CT 数が増加する事で，いずれの 捨て耳密度による成形品についても通気抵抗值が増加する ことが分かる. また， CT 数が少ないと通気抵抗值は捨て 耳密度の大きな Cord C で大きく密度の小さな Cord A で 小さくなるが, CT 数の増加と共にその差は小さくなり, CT 5 において各C ord の通気抵抗值はほぼ一定值となる 事が分かる。多孔質体の通気特性は, 成形品内部を通過す る流体と繊維間の接触面積に大きく依存する. 従って, 先 述のように, CT 数の増加により捨て耳の開繊が進み，通 過する流体に接触する繊維表面積が増加することによって 通気抵抗值も大きくなったものと考えられる。また，捨て 耳密度が小さい場合には, 前節における観察からも CT 数 が 1 回であっても捨て耳の開繊が進み繊維表面積が大きく なり通気抵抗值は比較的大きく, 一方, 密度が大きい場合 には CT 数が 1 回では捨て耳の開繊が不足する為に繊維表 面積が小さくなり, 通気抵抗值が小さくなったものと考え

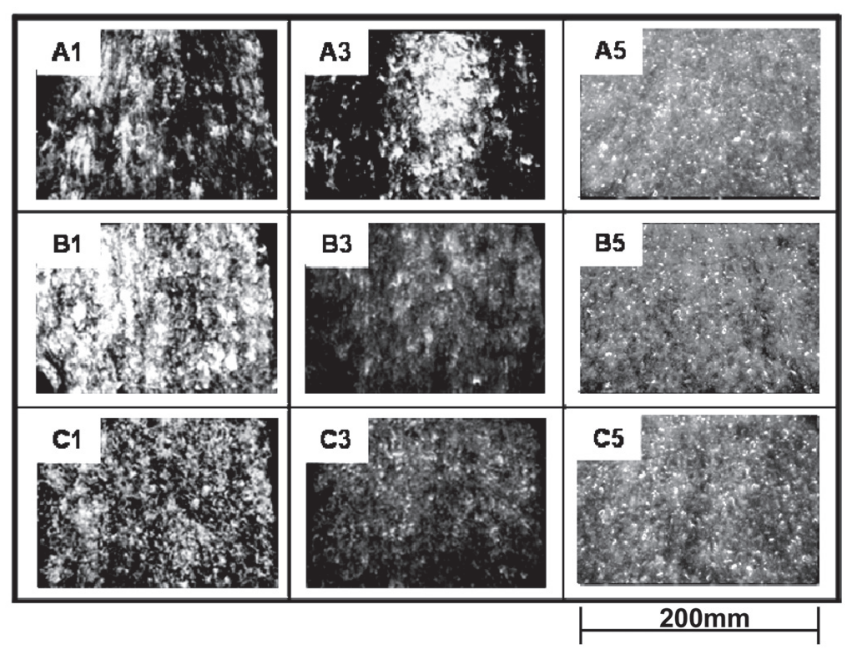

Fig. 6 Observation of carding condition

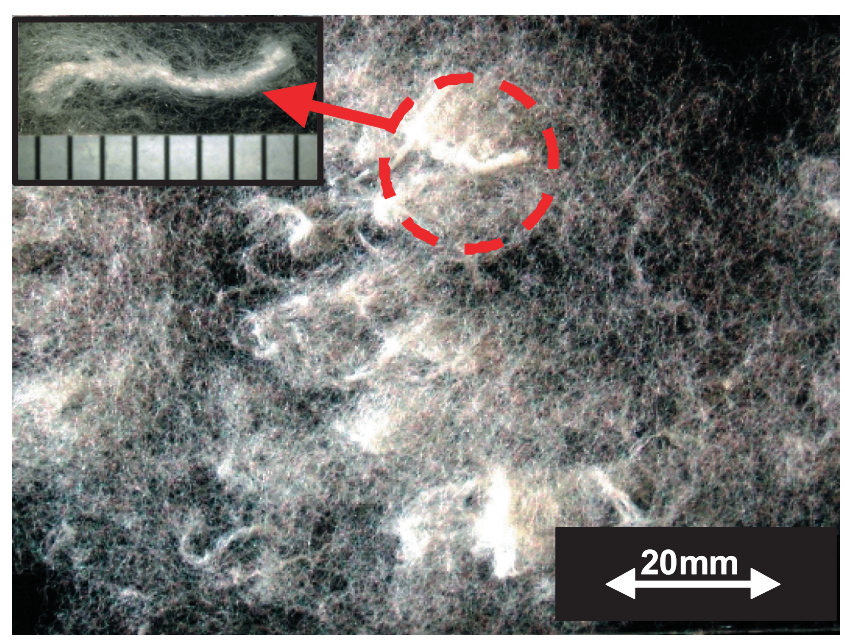

(a) Discarded part

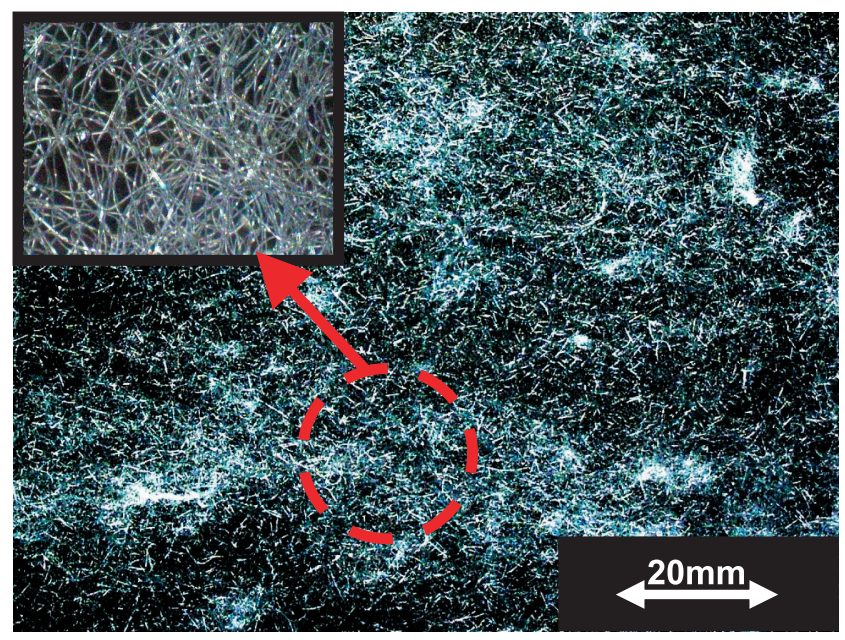

(b) Well carded part

Fig. 7 Microscopic observation of web

られる。しかし，CT 数が増加する事によって捨て耳密度 に関わらず開繊状態が一様な状態となる為に, 繊維表面積 の差異が小さくなり CT 数が 5 回となった時には捨て耳密 度に関わらず通気抵抗值がほぼ同一の值を示したものと考 


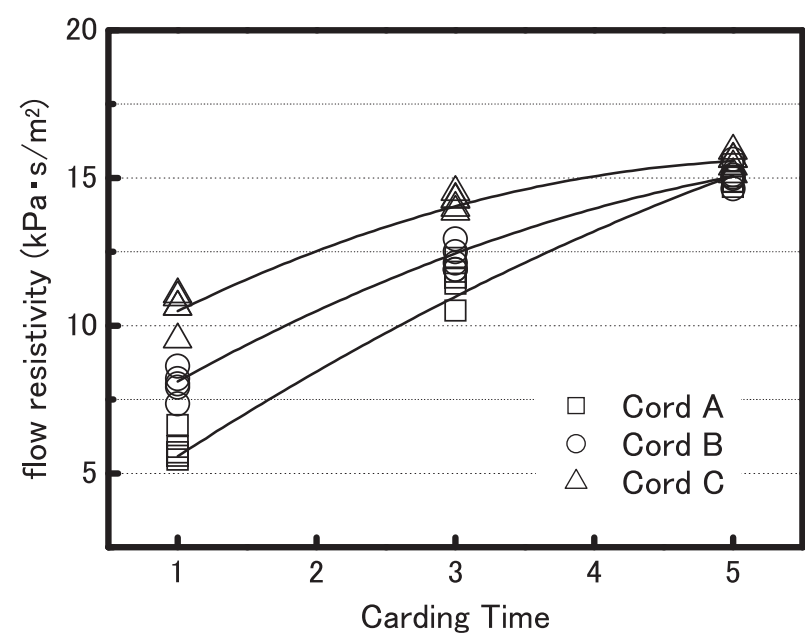

Fig. 8 Relation between flow resistivity and carding time

\section{えられる。}

これらのことから，ウェブの通気抵抗值を増大させるに は開繊工程を十分に行う必要があり，特に密度の大きな捨 て耳に対しては開繊工程を繰り返す必要のある事が明らか である。

\section{3 吸音性能}

Fig. 9〜11は，成形品の吸音率と周波数との関係を CT 数をパラメータとして各Cord 毎に示している。図より明 らかなように，いずれの Cord を用いた場合においても吸 音率は周波数の増加に伴って単調に増加しており，捨て耳 を素材とする吸音材は多孔質型吸音材の典型的な特性を有 する事が明らかである。

Fig. 12〜14 は吸音率に及ぼす CT 数の影響をそれぞれ 周波数が $800 \mathrm{~Hz}, 1250 \mathrm{~Hz}$ 及び $1600 \mathrm{~Hz}$ の場合を例に示し ている. 図より明らかなように，いずれの周波数において も吸音率は CT 数の増加に伴って増加し, その増加割合は 捨て耳密度が高い程小さくなる。また，いずれの周波数に おいても CT 数の増加に伴って吸音率が一定值に収束する 事が分かる.これらの傾向は前述の通気抵抗值における傾 向と良く一致している.

そこで, Fig 15 に吸音率と通気抵抗值の関係を周波数が $800 \mathrm{~Hz}, 1250 \mathrm{~Hz}$ 及び $1600 \mathrm{~Hz}$ の場合を例に表している. 同時に，各通気抵抗值での MIKI モデル及び DelanyBazley モデルによる予測吸音率も併せて示してある。

ここで, MIKI モデル及び Delany-Bazley モデルは様々 な繊維多孔質材料の吸音に関する特性值と通気抵抗值との 相関図から回帰的にフィット関数を導きだしたモデルであ り，通気抵抗值をパラメータとして簡便に繊維多孔質材料 の吸音率を定性的に予測する事が出来ると言われている ${ }^{9}$. 本報では，吸音率の予測に際し，パラメー夕となる通気抵 抗值は前節での測定によって得られた結果を用いた. MIKI モデル及び Delany-Bazley モデルは，(4)〜 (9) 式に示す 共通した形の線形方程式により表されるが，それぞれ試験 条件の違いや回帰フィットの方式が違う為に(6)〜 (9) 式内 の係数及び乗数 $(\delta, \phi, \eta, \varepsilon, p, q, r, s)$ が異なっ ている．両モデルの係数及び乗数を整理したものを Table 2 に示す.それぞれのモデルから得られた特性インピーダ

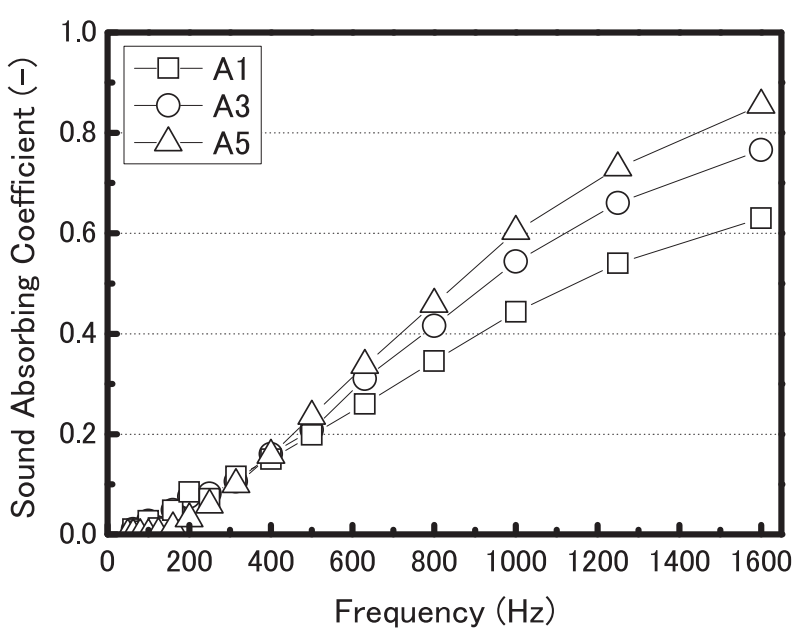

Fig. 9 Sound absorption coefficient at various carding time (cord A)

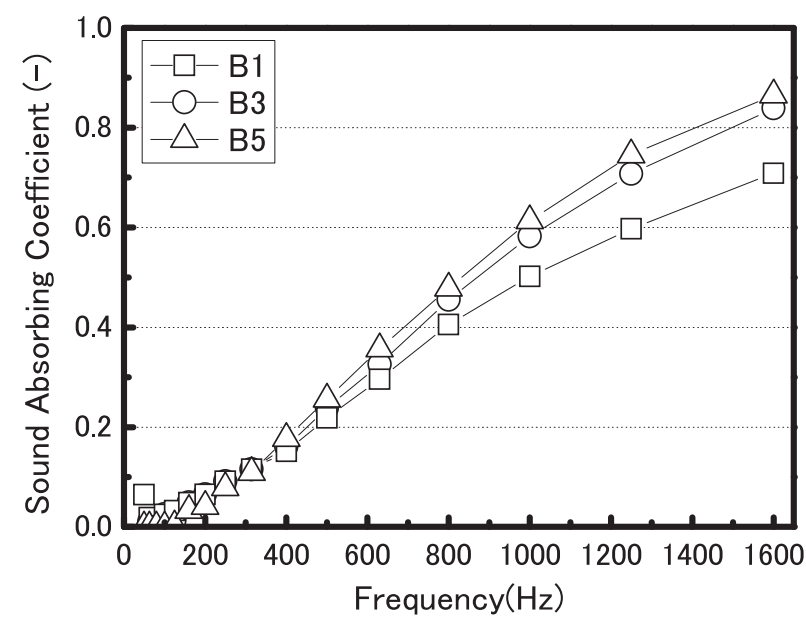

Fig. 10 Sound absorption coefficient at various carding time (cord B)

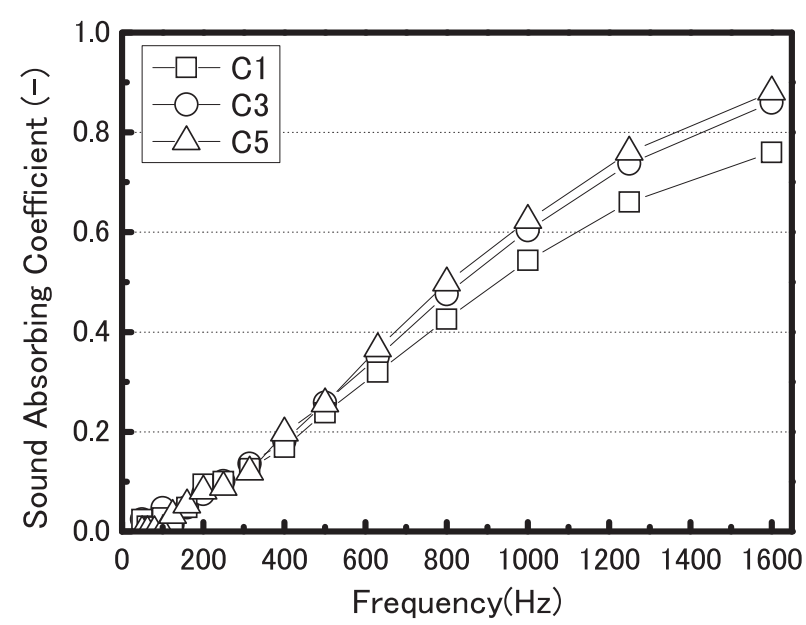

Fig. 11 Sound absorption coefficient at various carding time (cord C) 


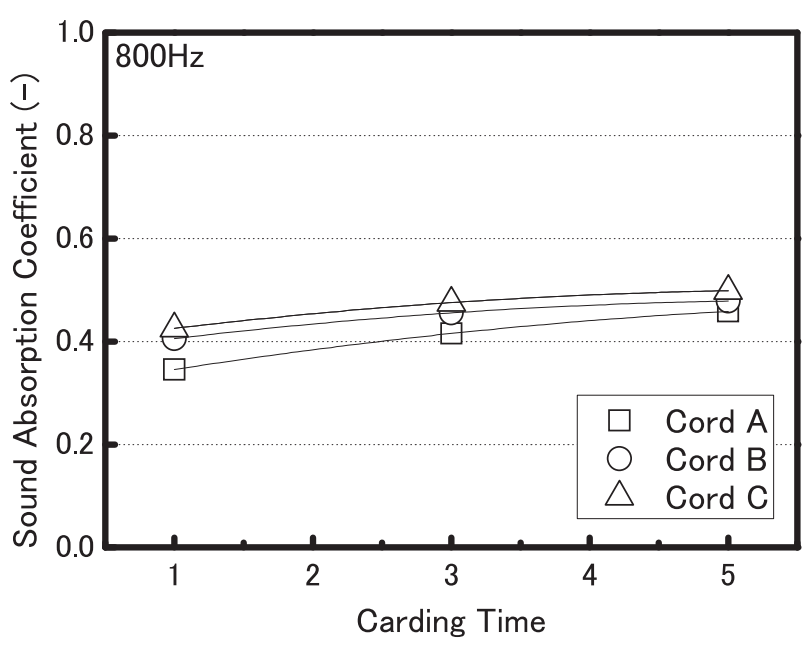

Fig. 12 Relation between sound absorption coefficient and carding time $(800 \mathrm{~Hz})$

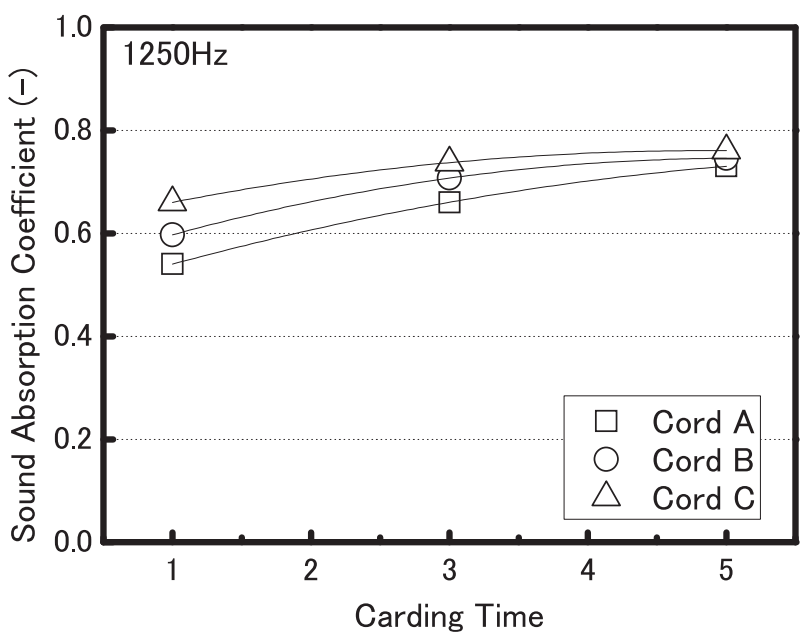

Fig. 13 Relation between sound absorption coefficient and carding time $(1250 \mathrm{~Hz})$

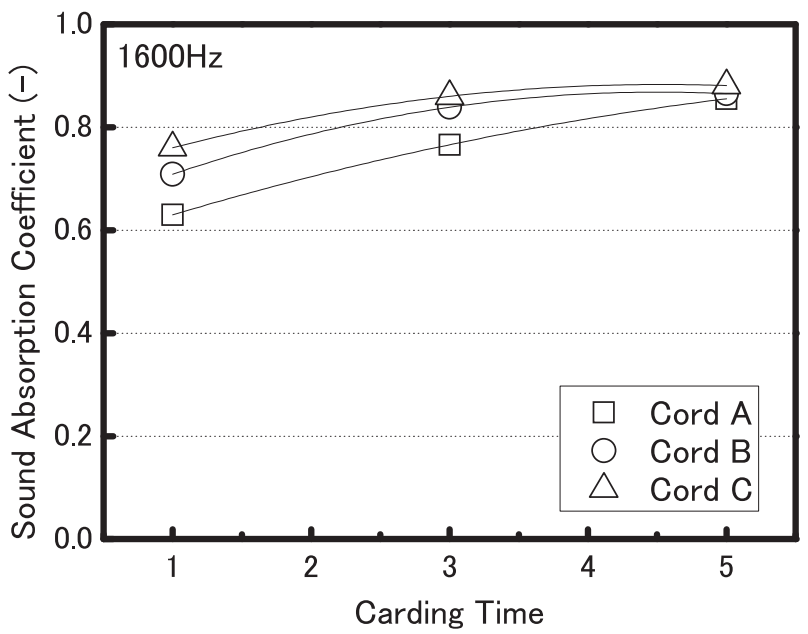

Fig. 14 Relation between sound absorption coefficient and carding time $(1600 \mathrm{~Hz})$
Table 2 Parameters in MIKI and Delany prediction model

\begin{tabular}{l|l|l|l|l|l|l|l|l}
\hline & $\delta$ & $\phi$ & $\eta$ & $\varepsilon$ & $p$ & $q$ & $r$ & $s$ \\
\hline MIKI & 0.0699 & -0.632 & 0.107 & -0.632 & 0.160 & -0.618 & 0.109 & -0.618 \\
\hline Delany & 0.0497 & -0.754 & 0.0758 & -0.732 & 0.169 & -0.595 & 0.0858 & -0.700 \\
\hline
\end{tabular}

ンス Zc 及び伝播定数 $\gamma$ を(2)式に代入することで比音響 インピーダンス $Z$ を得ることが出来，(3)式にこれを代入 することで垂直入射吸音率 $\alpha$ を導出することが出来る.

$$
\begin{gathered}
Z_{C}=\rho c\{X(f)+j Y(f)\} \\
\gamma=A(f)+j B(f) \\
X(f)=1+\delta\left(\frac{f}{\sigma}\right)^{\psi} \\
Y(f)=-\eta\left(\frac{f}{\sigma}\right)^{\varepsilon} \\
A(f)=\left(\frac{\omega}{c}\right)\left[p\left(\frac{f}{\sigma}\right)^{q}\right] \\
B(f)=\left(\frac{\omega}{c}\right)\left[1+r\left(\frac{f}{\sigma}\right)^{s}\right]
\end{gathered}
$$

ここで, $\sigma$ は通気抵抗值, $f$ は周波数, $\omega$ は角周波数で ある. $\rho$ 及び $c$ の值には, $20^{\circ} \mathrm{C}$ における空気の密度 $(1.2$ $\left.\mathrm{kg} / \mathrm{m}^{3}\right)$ 及び音速 $(346 \mathrm{~m} / \mathrm{s})$ を用いた。

Fig. 15 より明らかなように, 本報で成形した材料に関す る各プロット点は各周波数において CT 数に関わらず一つ の曲線で近似する事が出来る。 また, 実測值と二つのモデ ルによる予測值の近似曲線を比較すると，これらの示す傾 向は通気抵抗值の増加と共に吸音率が増加する点でほぼ一 致している事が分かる，すなわち，本報の捨て耳を素材と する成形品は，一般的な繊維多孔質吸音材において成り立 つ通気抵抗值と吸音性能の関係が，同様に成り立つ材料で あることが明らかである，尚，予測值と実測值には定量的 な相違が見られるが，これは先述のように，これらの予測 モデルは，種々の通気抵抗值及び吸音率の実測の結果から 回帰的に構築されたモデルであり, 予測対象とする材料の 通気抵抗值以外のパラメー夕が考慮されていない為である。

最後に，本研究において捨て耳を素材として成形を行っ た多孔質吸音材の吸音性能の位置付けを明確にする為に, 実験範囲内で最も高い吸音率を示した C 5 材と, Table 3 に示す現在広く用いられている各種（GW：グラスウール， EPDM : エチレンプロピレンゴム, PU：ポリウレタン)の 吸音構造体との吸音率を比較した結果を Fig. 16 に示す. なお,ここで各種の吸音構造体は繊維径や材料構造, さらに は密度がそれぞれに異なっており，それぞれのパラメー夕 が複雑に吸音率に影響している為に直接的な比較は出来な 


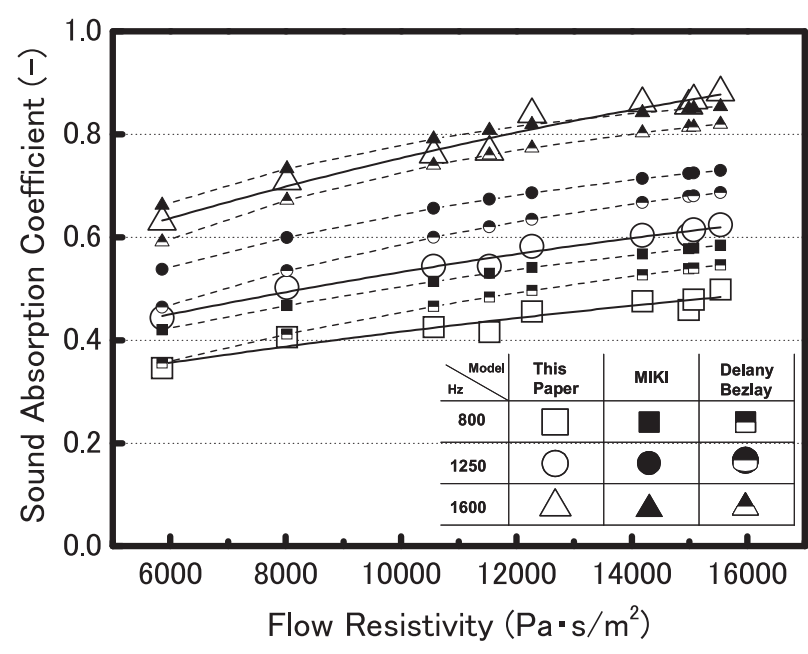

Fig. 15 Relation between sound absorption coefficient and flow resistivity (comparison of measured value and predicted value)

Table 3 Specifications of sound absorber generally used

\begin{tabular}{c|c|c|c}
\hline Sample & Structure Type & $\begin{array}{c}\text { Density } \\
\left(\mathrm{kg} / \mathrm{m}^{3}\right)\end{array}$ & $\begin{array}{c}\text { Fiber Diameter } \\
(\mu \mathrm{m})\end{array}$ \\
\hline $\mathrm{GW}$ & Fiber & 32 & 10 \\
\hline EPDM & Foam & 48 & - \\
\hline PU & Sheet & 128 & - \\
\hline
\end{tabular}

いが，本報で成形した吸音材のレベルを知ることが出来る.

図より明らかなように，本報で成形した材料の吸音性能 は従来品の吸音性能に対して大きな優位性を持つとは言え ないものの，廃材利用及び易リサイクル性の観点から，本 成形品は環境に優しい汎用的な吸音材としての利用価值を 有するものと考えられる。

\section{5. 結言}

本報ではポリエステル（PET）織物の製造時に発生す る捨て耳の多孔質吸音材素材としてのリサイクル性につい て検討した結果，以下に示す知見を得た。

1 ）捨て耳とバインダー繊維の混合ウェブを加熱圧縮成形 することによって多孔質型吸音材の成形が可能である。

2 ）成形品の吸音特性は，捨て耳の開繊状態と大きな関連 性が在り，捨て耳の開繊を進める事により成形品の吸 音性能も向上する.

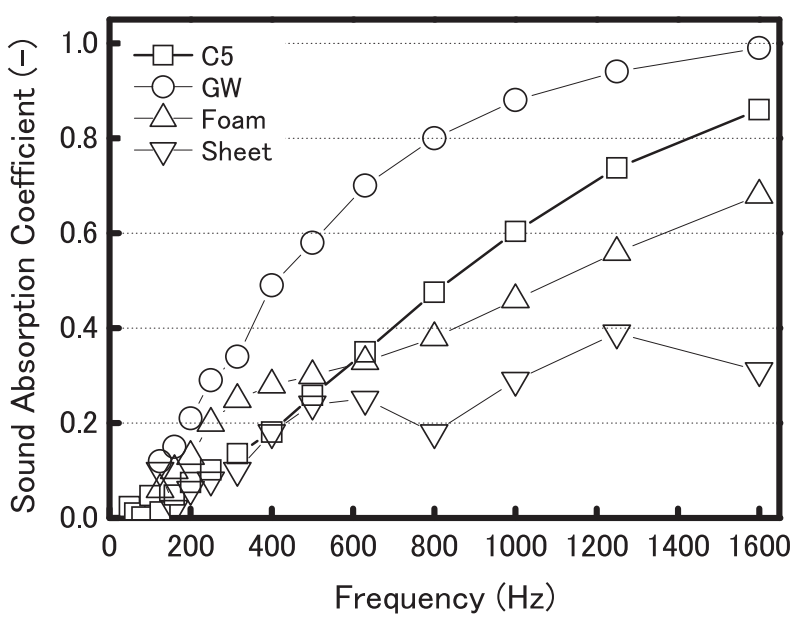

Fig. 16 Comparison of sound absorbing level

3 ）捨て耳を素材とする成形品の吸音特性は，通気抵抗値 と大きな相関があり，典型的な多孔質型吸音材として の特性を示す。

4 ）現在用いられている繊維多孔質型，発泡型及び膜材料 型の一般的な吸音材に対して，本成形品は同等レベル の吸音性能を示し, 環境調和型多孔質吸音材として十 分に利用価值を有する.

本研究は, 財団法人日本科学協会の平成 20 年度笹川科 学研究助成 (20-240) による研究の一環として遂行された. ここに記して深謝する。

\section{参 考 文 献}

1 ）木村照夫：成形加工，19(7)，417，2007

2 ）木村照夫：成形加工，17(10)，715，2005

3 ）前川純一, 森本政之, 坂上公博: 建築環境音響学第 2 版 (南篠光章), 72 (2004), 共立出版

4 ）渡辺恭一：自動車技術，51（7），60，1997

5 ）木下陸肥路：日本音響学会誌，23(6)，415，1967

6 ) Delany, M. E. and Bazley, E. N. : Applied Acoustics, 3, 105,1970

7 ) Miki, Y. : J. Acoustic Soc Jpn, 11, 19, 1990

8 ）日本規格協会：JIS Hand Book No.9（日本規格協 会)，1520(2008)，日本規格協会

9 ) Komatsu, Takeshi : Acoustic Science and Technology, $29(2), 121,(2008)$ 